\begin{tabular}{|c|c|c|}
\hline Dinamika Journal, Vol. 2 No. 2, 2020 & ISSN ONLINE : 2686-2158 \\
\hline
\end{tabular}

\title{
TRANSFER TEKNOLOGI PEMBUATAN PELLET ORGANIK UNTUK PAKAN IKAN
}

\author{
Agatha Sih Piranti, ${ }^{1, *}$, Diana RUS Rahayu ${ }^{1)}$, Gentur Waluyo ${ }^{2)}$ \\ ${ }^{1)}$ Fakultas Biologi, Universitas Jenderal Soedirman, Purwokerto, Indonesia \\ ${ }^{2)}$ Fakultas Teknik, Universitas Jenderal Soedirman, Purbalingga, Indonesia \\ *Corresponding author: agatha.piranti@gmail.com
}

Received 27 September 2019; Accepted 26 April 2020; Available online 30 April 2020

\begin{abstract}
Abstrak
Pakan merupakan salah satu faktor utama yang harus diperhatikan mengingat dalam kurun waktu produksi, kontribusi pakan dapat mencapai 60\% dari total biaya produksi. Dengan meningkatnya harga bahan baku pakan akan menyebabkan biaya produksi meningkat hal ini dapat menurunkan tingkat keuntungan bagi petani ikan. Sehubungan dengan hal tersebut maka telah dilakukan alih teknologi untuk memberikan pemahaman dan ketrampilan kepada petani ikan di Desa Pasir kulon Kecamatan Karang lewas untuk memproduksi pellet organik dengan bahan baku tanaman eceng gondok dan cacing tanah. Pendekatan metode yang dilakukan dalam kegiatan ini menggunakan metode PRA (Partisipatory Rural Appraisal) yang meliputi pembekalan teori, praktek, demonstrasi plot dan selanjutnya dilakukan monitoring dan evaluasi. Proses produksi dimulai dengan pemilihan bahan baku yang berkualitas, penyusunan komponen bahan baku sesuai jenis ikan yang dituju, penghitungan kebutuhan bahan baku yang akan digunakan, pembuatan pellet. Hasil evaluasi teori dan ketrampilan peserta kegiatan menunjukkan adanya peningkatan pemahaman dan ketrampilan peserta (petani ikan) terhadap kemampuan dalam melakukan produksi pakan buatan sendiri. Hasil evaluasi dampak menunjukkan adanya perubahan perilaku dan pola pikir peserta.
\end{abstract}

Kata kunci : pellet organik, eceng gondok, cacing tanah.

\section{Abstract}

Feed is one of the main factors that must be considered considering that in the production period, the contribution of feed can reach $60 \%$ of the total production cost. Increasing the price of feed raw materials will cause increased production costs, this can reduce the level of profit for fish farmers. In connection with this matter, transfer of technology has been carried out to provide understanding and skills to fish farmers in Pasir Kulon Village, Karang Lewas District to produce organic pellets with raw materials for water hyacinth and earthworms. The method approach taken in this activity uses the PRA (Participatory Rural Appraisal) method which includes provisioning theory, practice, demonstration plots and subsequently monitoring and evaluation. The production process begins with the selection of quality raw materials, preparation of components of raw materials according to the intended fish species, calculation of raw material requirements to be used, pellet making, and packaging, and also application to cultured fish. The results of the evaluation of the theory and skills of the 
activity participants showed an increase in the understanding and skills of the participants (fish farmers) on the ability to produce homemade food. The results of the impact evaluation indicate changes in the behavior and mindset of the participants.

Keywords: organic pellets, water hyacinth, earthworms

\section{PENDAHULUAN}

Kabupaten Banyumas, telah dicanangkan sebagai daerah minapolitan berbasis perikanan budidaya. Hal tersebut merupakan suatu upaya pemerintah daerah dalam meningkatkan kesejahteraan masyarakat khususnya pembudidaya ikan di Kabupaten Banyumas.

Desa Pasir Kulon, Kecamatan Karanglewas, Kabupaten Banyumas, Jawa Tengah merupakan salah satu desa yang diupayakan oleh Pemerintah Daerah Kabupaten Banyumas sebagai kawasan budidaya perikanan. Salah satu upaya untuk mewujudkannya adalah dengan melakukan kegiatan "Transfer Teknologi pembuatan pellet organik untuk pakan ikan. Berdasarkan data monografi Tahun 2016, jumlah kolam permanen yang terdapat di Desa Pasir Kulon lebih dari 100 unit dengan luas bervariasi dari $3 \times 4 \mathrm{~m}^{2}$ hingga $12 \times 9 \mathrm{~m}^{2}$ yang semuanya digunakan untuk aktifitas budidaya ikan air tawar di antaranya lele, nilem, nila, mujair, mas dan gurami. Pakan yang diberikan selama pemeliharaan umumnya berupa pakan buatan (pellet) komersial yang banyak beredar di pasaran dengan harga yang relatif mahal. Oleh karena itu kondisi tersebut mempengaruhi biaya operasional sehingga berakibat pada tingginya harga jual ikan. Di samping itu pellet komersial yang sering digunakan oleh para pembudidaya ikan di desa Pasir kulon, selain harganya mahal (Rp. 14.000/kg) kualitasnya juga rendah, karena komposisi nutrisi yang tertera dalam kemasan tidak sesuai dengan kandungannya. Menurut Afrianto \& Liviawati (1988), bahwa pakan merupakan sumber energi yang dibutuhkan ikan mulai dari benih hingga ukuran dewasa. Iskandar \& Elrifadah (2015) menyatakan bahwa untuk mempertahankan kelangsungan hidup selama terjadinya perubahan jenis pakan (pakan internal ke pakan eksternal) diperlukan komposisi nutrisi yang sesuai dengan kebutuhan metabolime dalam tubuh organisme tersebut. Oleh karena itu ketersediaan pakan dalam jumlah yang tepat dan komposisi nutrisi yang sesuai sangat diperlukan dalam melakukan budidaya ikan. Para pembudidaya ikan di desa Pasir Kulon tidak menggunakan pakan buatan tetapi menggunakan pakan alami berupa plankton yang dipacu pertumbuhannya menggunakan pupuk kandang. Sedangkan penggunaan pupuk kotoran hewan (pupuk kandang) yang tidak sesuai takaran akan mengakibatkan penurunan $\mathrm{pH}$ air maupun substrat dasar kolam. Selain itu kebutuhan pakan ikan budidaya tidak dapat terpenuhi dengan ketersediaan plankton yang ada di kolam, karena untuk pertumbuhan membutuhkan energi yang semakin besar. Oleh karena itu seringkali pembudidaya di Desa Pasir memberi pakan ikan peliharaannya menggunakan sisa-sisa makanan atau limbah rumah tangga, tanaman apu-apu (Azolla pinata), daun sente dan beberapa tumbuhantumbuhan gulma seperti eceng gondok yang dicincang. Keadaan tersebut tentunya tidak akan mampu mendukung kelangsungan hidup dan pertumbuhan ikan secara maksimal. Oleh karena itu agar produksi perikanan di Desa Pasirkulon meningkat perlu adanya suatu inovasi yang menggunakan teknologi sederhana dan mudah dipahami khususnya oleh para pembudidaya ikan. Tetapi mampu meningkatkan produksi perikanan serta memanfaatkan bahan baku yang tersedia di sekitar wilayah Desa Pasir kulon sehingga mudah diperoleh.

Aplikasi teknologi sederhana yang diperlukan oleh para pembudidaya ikan di desa Pasir kulon khususnya adalah dalam hal penyediaan pakan. Pakan untuk pembesaran ikan golongan carnivora dan omnivora seperti lele, nila, bawal dan gurami harus mengandung nutrisi yang lengkap meliputi protein, lemak, karbohidrat, mineral dan vitamin. Kurangnya komponen nutrisi dalam ransum pakan yang diberikan dapat mengakibatkan terjadinya 
kelainan metabolisme, selanjutnya dapat menyebabkan pertumbuhan atau laju kelangsungan hidup ikan akan terganggu (Afrianto dan Liviawaty, 1999). Pengetahuan dan teknologi sederhana dalam pembuatan pellet organik dengan bahan baku cacing tanah sebagai sumber protein hewani dan tanaman eceng gondok sebagai sumber karbohidrat (serat), merupakan salah satu alternatif yang dapat dilakukan untuk menyelesaikan permasalahan kebutuhan pakan.

Pakan merupakan salah satu faktor utama yang harus diperhatikan mengingat dalam kurun waktu produksi, kontribusi pakan dapat mencapai $60 \%$ dari total biaya produksi (Afrianto dan Liviawaty, 2005). Selanjutnya menurut Direktorat Kelautan dan Perikanan (2011), bahwa proyeksi kebutuhan pakan ikan selama 5 tahun (2010-2014) sebanyak 6 juta ton. Nilai nutrisi pakan umumnya dilihat dari komposisi gizinya yang terdiri dari kandungan protein, lemak, serat kasar, karbohidrat, vitamin, mineral dan kadar air. Salah satu komponen nutrisi penting untuk ikan adalah protein, sehingga kekurangan protein dalam pakan dapat mengakibatkan terhambatnya pertumbuhan.

Bahan-bahan baku yang dapat digunakan sebagai pakan ikan sangat banyak dan bervariasi baik masih berupa bahan mentah maupun bahan hasil olahan diantaranya dedak, ampas tahu, bungkil kelapa, tepung jagung, tepung kedelai, tepung daun (singkong, turi, dan lain-lain), tepung tulang (ikan, ayam), tepung kepala udang, tepung darah, limbah jamur dan lain-lain. Komponen yang mutlak diperlukan oleh ikan adalah protein yang merupakan komponen penunjang aktivitas enzim dan hormon pertumbuhan. Salah satu sumber protein hewani yang belum termanfaatkan secara maksimal sebagai campuran dalam komponen pakan ikan adalah cacing tanah (Lumbricus rubellus). Cacing tanah termasuk dalam kelompok hewan invertebrata (tidak bertulang belakang), berwarna kemerahan (pink), panjang berkisar antara 7,5-10 $\mathrm{cm}$. Cacing tanah mengandung kadar protein yang cukup tinggi yaitu sebesar $76 \%$, karbohidrat sebesar $17 \%$, lemak sebesar $4,5 \%$ dan abu sebesar 1,5\% (Taris et al, 2018). Selain komponen protein sebagai sumber energi untuk aktivitas, pertumbuhan dan reproduksi serta daya tahan tubuh, ikan juga membutuhkan komponen karbohidrat dan serat kasar. Sumber karbohidrat umumnya dapat ditemui dalam bahan nabati seperti tepung jagung, gandum, singkong, daun singkong dan turi. Salah satu bahan nabati yang belum banyak dimanfaatkan sebagai sumber karbohidrat pada pakan ikan adalah eceng gondok. Eceng gondok merupakan fauna akuatik yang banyak ditemukan diperairan tawar seperti rawa, danau, tepian sungai bahkan di beberapa kolam ikan. Tanaman air ini dianggap sebagai gulma karena keberadaannya seringkali menyebabkan beberapa permasalahan (Ramlan \& Indrianti, 2018). Selanjutnya menurut Nugraha \& Mikdarullah (2016), eceng gondok yang selama ini dikenal sebagai gulma air yang mengganggu dan sulit dibasmi ternyata dari beberapa penelitian diketahui mempunyai kandungan protein yang cukup tinggi yaitu antara 12-18 \% serta kandungan asam amino cukup lengkap. Hasil analisis kimia menunjukkan bahwa eceng gondok mengandung bahan organik yang kaya akan vitamin dan meneral, juga mengandung protein dan lemak yang cukup tinggi.

Dengan adanya potensi dari cacing tanah dan eceng gondok sebagai bahan baku pellet organik maka hal tersebut diharapkan dapat mendukung pertumbuhan ekonomi desa dan meningkatkan kesejahteraan masyarakat khususnya pembudidaya ikan dengan menyediakan sumber protein hewani yang murah dan praktis, karena diperoleh dari lingkungan sekitar. Dengan transfer teknologi tersebut diharapkan masyarakat Pasir Kulon terampil membuat pellet sendiri sehingga tercipta lapangan kerja baru bagi masyarakat.

Kegiatan ini, bertujuan sebagai berikut:

1. Melakukan penyuluhan tentang manfaat pellet organik berbahan baku cacing tanah dan tepung eceng gondok untuk kesehatan ikan.

2. Melakukan pelatihan pembuatan pakan buatan berbahan baku cacing tanah dan tepung eceng gondok untuk kesehatan ikan. 
Manfaat kegiatan ini untuk meningkatkan ketrampilan para pembudidaya ikan di Desa Pasir kulon dalam membuat pakan buatan (pellet) organik yang berprotein tinggi. Dengan kegiatan ini juga dapat meningkatkan pendapatan pembudidaya ikan dengan membuat produk pakan buatan secara mandiri dan ekonomis. Kegiatan ini juga bermanfaat untuk membantu memberikan nilai manfaat terhadap gulma air khususnya eceng gondok yang dianggap dapat menimbulkan permasalahan bagi lingkungan.

\section{METODE PELAKSANAAN}

Pendekatan metode yang dilakukan dalam kegiatan ini menggunakan metode PRA (Partisipatory Rural Appraisal). Metode PRA adalah suatu metode pendekatan dalam proses pemberdayaan dan peningkatan partisipasi masyarakat, yang tekanannya pada keterlibatan masyarakat dalam keseluruhan kegiatan pembuatan pellet organik ini meliputi pembekalan materi yang dilakukan melalui penyuluhan/ceramah, praktek dan demostrasi plot (demplot).

\section{Pembekalan materi dilakukan melalui ceramah}

Pembekalan materi/informasi secara oral dimaksudkan sebagai manivestasi transfer teknologi kepada khalayak sasaran (kelompok pembudidaya ikan Desa Pasir Kulon) berupa teknik pembuatan pakan organik dengan bahan baku cacing tanah dan tanaman eceng gondok. Materi ceramah meliputi : teknik pemilihan bahan baku berdasarkan kandungan nutrisinya, penyusunan komposisi pakan untuk jenis ikan tertentu, penghitungan kebutuhan bahan baku dengan menggunakan 2 metode, yaitu metode kwadrat dan metode persentase, teknik pembuatan pellet yang disertai praktek secara langsung, dan terakhir disampaikan pula teknik pengemasan yang benar agar pellet tahan dalam jangka waktu tertentu.

Kegiatan praktek dimaksudkan untuk meningkatkan pemahaman materi dan ketrampilan khalayak sasaran secara nyata untuk menumbuhkan kreatifitas serta kemauan belajar menanggulangi permasalahan yang kemungkinan dihadapi dalam pelaksanakan penyediaan stok pakan dalam budidaya ikan.

\section{Diskusi dan evaluasi.}

Selama proses transfer teknologi diselenggarakan sesi diskusi dan tanya jawab yang dilakukan pada saat penyampaian materi secara langsung (oral) dan praktek dengan tujuan memperjelas materi yang disampaikan.

\section{Demonstrasi Plot}

Demontrasi plot meliputi kegiatan pemilihan bahan baku yang berkualitas, penyusunan komponen pakan sesuai dengan jenis ikan tertentu, penghitungan kebutuhan bahan baku menggunakan metode kwadrat dan persen, pembuatan pellet berbahan baku cacing tanah dan eceng gondok, penjemuran pellet, dan aplikasi pellet organik ke ikan budidaya, serta pengemasan.

\section{Evaluasi}

Evaluasi dilakukan untuk mengetahui hasil transfer teknologi berupa teori dan praktek yang dilakukan baik melalui wawancara secara langsung, tertulis maupun berdasarkan hasil praktek yang dilakukan. Evaluasi yang dilakukan meliputi :

- Evaluasi teori

Evaluasi teori/pengetahuan tentang sistematika proses produksi pembuatan pakan organik berbahan baku eceng gondok dan tepung cacing tanah, yang dilakukan untuk mengetahui sejauh mana tingkat pemahaman teori yang diberikan dapat diterima peserta. Evaluasi dilakukan dalam bentuk pre test pada awal kegiatan sebelum disampaikan pembekalan teori/materi penyuluhan dan post test yang dilakukan setelah seluruh kegiatan terlaksana. Disamping kedua hal tersebut juga dilakukan tanya jawab secara langsung pada 
saat pembekalan teori/penyuluhan. Indikator peningkatan pengetahuan terjadi apabila nilai post test lebih tinggi dari pada nilai pre test.

- Evaluasi ketrampilan

Evaluasi ketrampilan yang meliputi cara pemilihan bahan baku, teknik penyususnan komposisi bahan baku sesuai dengan kebutuhan jenis ikan tertentu, penghitungan kebutuhan baku dan cara pembuatan pakan organik yang dilakukan pada saat praktikum dan demonstrasi plot. Indikator keberhasilan adanya peningkatan ketrampilan diketahui dari kemampuan peserta dalam proses produksi dan hasil produksinya serta kemampuan dalam penanganan pasca produksi/pengemasan.

- Evaluasi dampak

Evaluasi dampak dilakukan untuk mengetahui terjadinya perubahan perilaku dan pola pikir masyarakat, khususnya para anggota pokdakan Mina Jaya dan masyarakat disekitarnya yang melakukan budidaya ikan dalam mempersiapkan stok pakan yang sesuai dengan jenis ikan yang dibudidayakan. Indikator tersebut dapat dilihat dari penurunan tingkat mortalitas ikan budidaya. Penggunaan pakan organik hasil pembuatan sendiri dapat berimbas pada peningkatan jumlah pendapatan petani ikan.

\section{HASIL DAN PEMBAHASAN :}

Hasil yang telah dicapai pada kegiatan ipteks yang dilakukan di Desa Pasir Kulon adalah sebagai berikut :

\section{A. Realisasi Pelaksanaan Program}

Kegiatan Pengabdian Kepada Masyarakat ini dibagi menjadi tiga tahap yang terdiri dari tahap persiapan, tahap pelaksanaan dan yang terakhir adalah tahap evaluasi dan monitoring (monev). Pada tahap persiapan, hal yang pertama dilakukan adalah pembuatan banner untuk memberikan informasi kepada masyarakat bahwa akan diadakan kegiatan PKM (Gamber 1). Tahap selanjutnya adalah menyusun jadwal kegiatan selanjutnya berkordinasi dengan mitra kegiatan yaitu petani ikan Desa Pasir kulon, konfirmasi ke perangkat Desa Pasir kulon terkait ijin pelaksanaan kegiatan, persiapan bahan dan alat yang diperlukan dalam praktikum dan pembuatan demplot serta penyusunan materi penyuluhan. Realisasi pelaksanaan program ini mulai dilaksanakan pada bulan Mei 2014, dengan melakukan persiapan bahan baku cacing dan eceng gondok (Gambar 2, 3 dan 4).

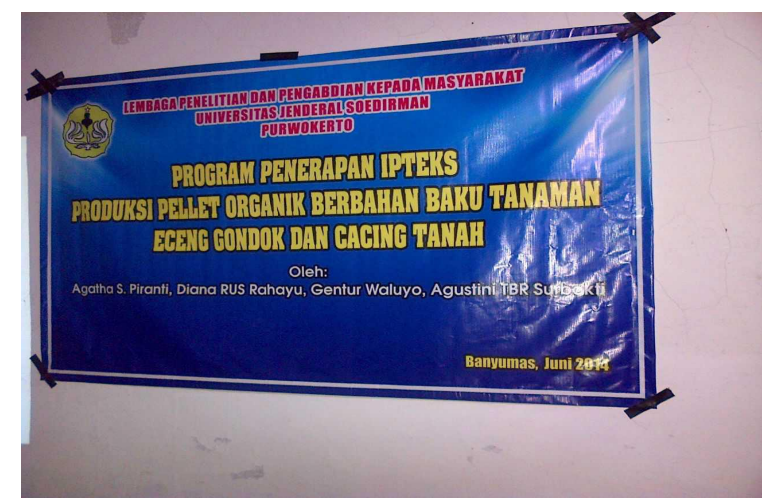

Gambar 1. Banner penerapan IPTEKS

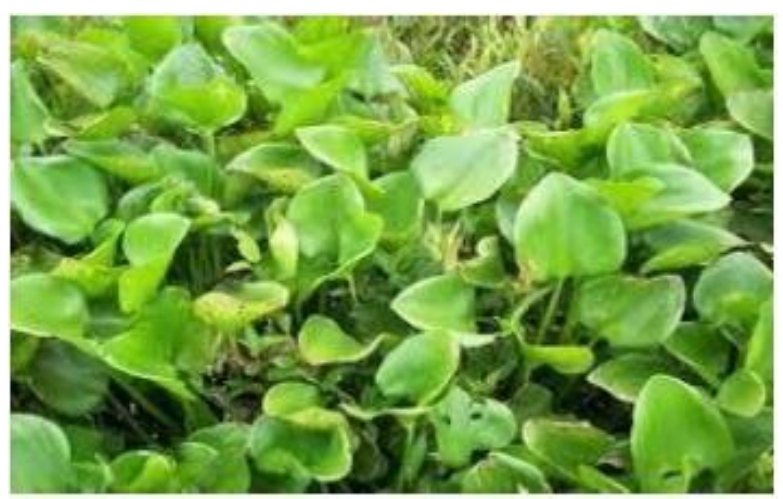

Gambar 2. Bahan baku eceng gondok 


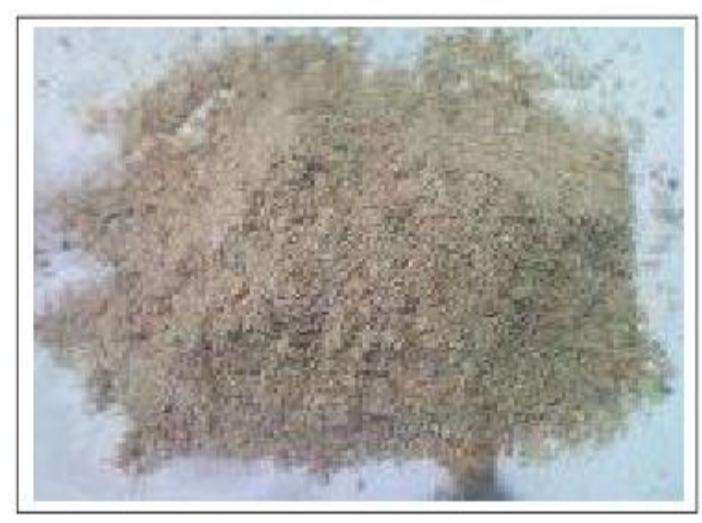

Gambar 3. Tepung eceng gondok

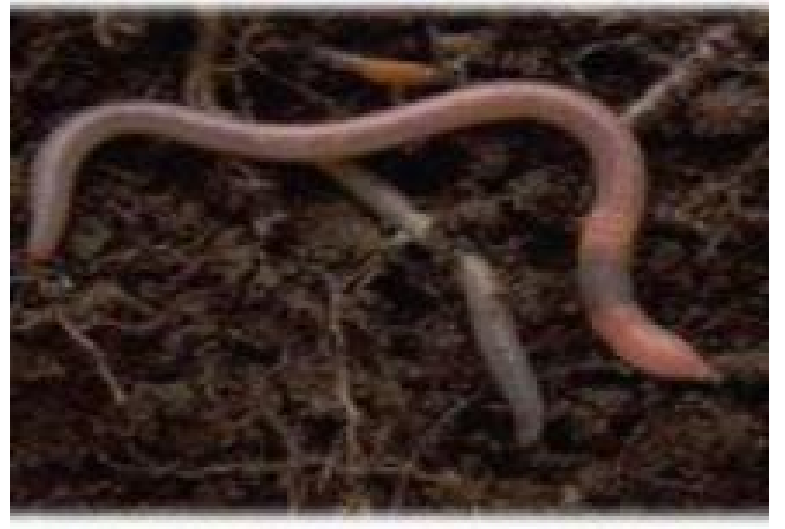

Gambar 4. Cacing tanah

Selanjutnya pada bulan Juni 2014 dilakukan pembekalan materi oleh Tim Pelaksana (Gambar 5) kepada 15 anggota Pokdakan yang hadir pada saat itu (Gambar 6 dan 7).

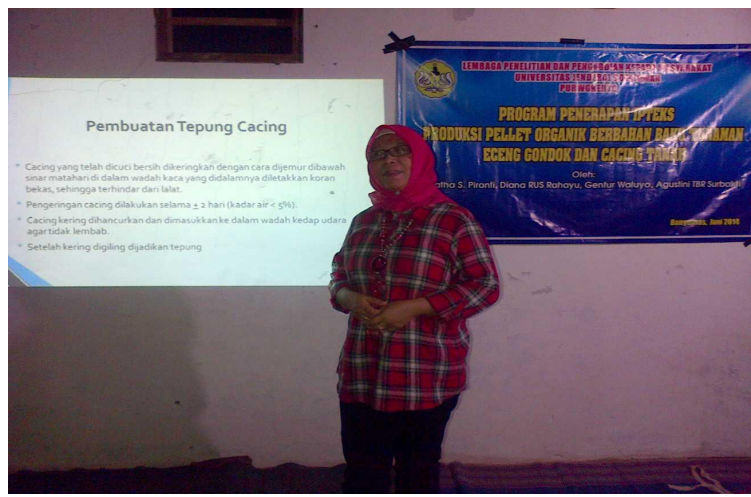

Gambar 5. Penyampaian materi

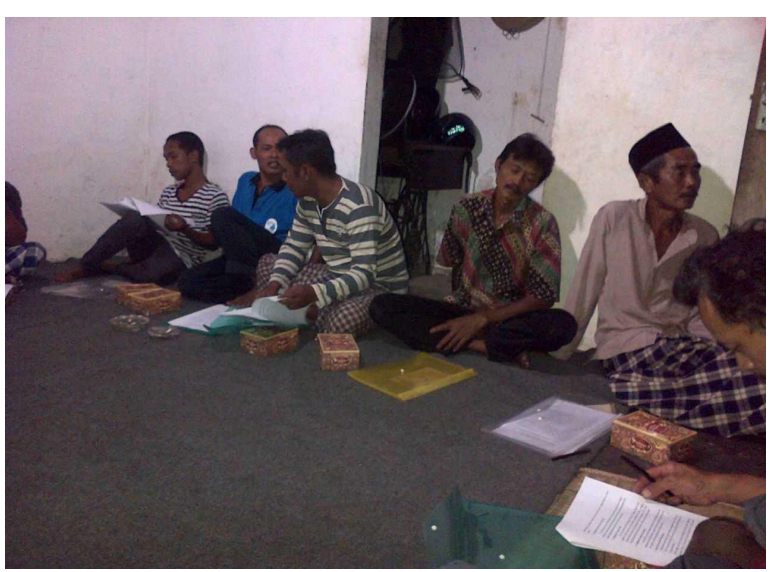

Gambar 6. Peserta pelatihan

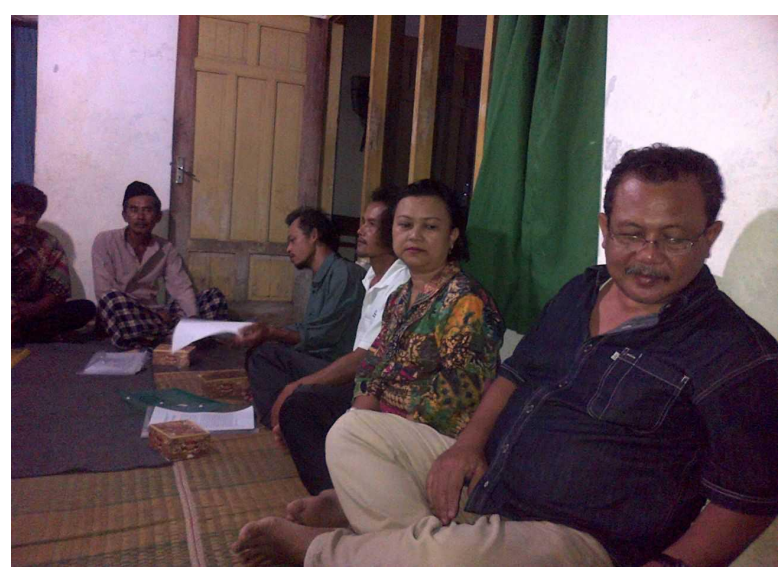

Gambar 7. Ramah tamah dan diskusi

Ceramah dilakukan pada malam hari dengan tujuan agar semua peserta dapat hadir, mengingat sebagian aktifitas/kegiatan perikanan para peserta dilakukan pada pagi hingga sore hari.

\section{B. Evaluasi Realisasi}

Tim penyuluh mengundang 18 orang peserta, namun hanya 15 orang yang dapat hadir. Peserta yang mengikuti kegiatan ini dipilih yang sudah mempunyai bekal atau dasar pengetahuan tentang budidaya ikan, bahkan peserta merupakan anggota kelompok pembudidaya ikan (pokdakan) yang berbasis di RT 02 RW 02 Desa Pasir kulon Kecamatan 
Karang lewas Kabupaten Banyumas. Realisasi kegiatan sesuai dengan jadwal kegiatan yang yang telah direncanakan.

Hasil pelaksanaan program pengabdian dapat dilihat dari segi fisik dan non fisik. Hasil fisik dievaluasi berdasarkan pemantauan sikap, perilaku dan aktivitas peserta selama kegiatan pembekalan materi, praktikum dan aplikasi kegiatan yang dilakukan oleh setiap perwakilan peserta. Sedangkan hasil non fisik dievaluasi berdasarkan pemahaman peserta terhadap materi pembekalan yang disampaikan dengan cara ceramah dan diskusi.

Pelaksanaan pembekalan materi yang dilakukan dalam bentuk ceramah dan praktikum memperlihatkan bahwa kegiatan tersebut ternyata mampu memperbaiki pola pikir, meningkatkan pengetahuan dan pemahaman serta menambah motivasi peserta untuk lebih mendalami tentang teknik pembuatan pakan ikan organik berbahan baku cacing tanah dan tepung eceng gondok. Penggunaan eceng gondok dipilih mengingat sebagian besar kolam, sawah dan perairan dilingkungan Desa Pasir kulon banyak terdapat dan tumbuh secara liar. Selain itu penggunaan eceng gondok dipilih karena mudah diperoleh, ekonomis karena tidak membeli dan efisien karena tersedia sepanjang waktu. Pemilihan tepung cacing tanah dipilih karena berdasarkan hasil penelitian, cacing tanah mampu menggantikan tepung ikan sebagai sumber protein hewani.

Evaluasi dampak terhadap hasil fisik yang telah dicapai dalam kegiatan ini, dimulai dari pembekalan materi, praktikum, pembuatan demplot, uji pemberian pellet organik pada ikan budidaya hingga upaya penyimpanan stok dalam kemasan plastik dan sampai dengan berakhirnya kegiatan monitoring. Berdasarkan hasil evaluasi menunjukkan bahwa hampir semua peserta kegiatan mampu menguasai teknik pembuatan pakan organik berbahan baku eceng gondok dan tepung cacing tanah dan aplikasinya untuk pakan ikan peliharaannya serta teknik pengemasannya untuk stok.

Evaluasi dampak terhadap hasil fisik yang telah dicapai dalam kegiatan ini, dimulai dari pembekalan materi, praktikum, pembuatan demplot, uji pemberian pellet organik pada ikan budidaya hingga upaya penyimpanan stok dalam kemasan plastik dan sampai dengan berakhirnya kegiatan monitoring. Berdasarkan hasil evaluasi menunjukkan bahwa hampir semua peserta kegiatan mampu menguasai teknik pembuatan pakan organik berbahan baku eceng gondok dan tepung cacing tanah dan aplikasinya untuk pakan ikan peliharaannya serta teknik pengemasannya untuk stok.

Faktor pendorong dan penunjang keberhasilan pelaksanaan kegiatan ini secara keseluruhan antara adalah adanya kerjasama yang baik antara tim pengabdian, seluruh peserta kegiatan dan perangkat Desa Pasir kulon. Disamping itu juga karena adanya dukungan dana dari Anggaran DIPA Unsoed Tahun 2012, dukungan sarana dan prasarana dari para peserta, dukungan sarana dan prasarana dari Stasiun Percobaan Prodi D-III Pengelolaan Sumberdaya Perikanan Fakultas Biologi. Sedangkan salah satu permasalahan yang dihadapi dalam aplikasi teknologi adalah perbedaan latar belakang dan tingkat pendidikan serta pengetahuan para peserta yang cukup beragam sehingga perlu metode atau cara yang lebih sederhana agar pembekalan materi dan praktek berlangsung dengan lancar. Namun demikian hal tersebut bukan merupakan suatu faktor penghambat bagi berlangsungnya kegiatan alih teknologi, mengingat penyampaian materi/pembekalan materi dilakukan dengan menggunakan bahasa yang mudah dipahami serta dilakukan diskusi.

\section{Evaluasi Hasil Produksi Pellet Organik}

Pellet merupakan pakan buatan yang mempunyai beberapa kelebihan dibanding pakan alami, antara lain dapat disimpan dalam waktu tertentu sehingga dapat digunakan setiap saat, dengan komposisi bahan yang disesuaikan dengan kebutuhan ikan peliharaan. Penggunaan pellet telah banyak dilakukan khususnya untuk tahap pembesaran, dimana kebutuhan pakan harus selalu tercukupi dalam waktu tertentu untuk meningkatkan pertumbuhan/bobot ikan. Pellet yang berkualitas tinggi selain mempunyai kandungan protein yang sesuai untuk 
kebutuhan ikan tertentu juga mempunyai daya simpan yang cukup lama. Pellet yang mempunyai kandungan protein tinggi biasanya mempunyai harga yang lebih mahal dibandingkan pellet yang kandungan proteinnya rendah. sumber protein umumnya diperoleh dari bahan hewani seperti tepung ikan. Namun demikian berdasarkan hasil penelitian Aslamyah dan Karim (2013), tepung cacing tanah dapat menggantikan tepung ikan sebagai sumber protein hewani pada pakan ikan Bandeng (Chanos chanos Forskal). Berdasarkan hasil aplikasi pellet yang diberikan pada ikan peliharaan petani peserta kegiatan, menunjukkan bahwa pertumbuhan ikan nila dan lele peliharaannya meningkat. Disamping itu respon makan pada ikan budidaya yang diberi pakan pelllet organik tersebut meningkat. Hal ini diduga selain aroma pellet organik yang merangsang juga karena komposisi pellet yang sesuai untuk ikan kelompok omnivora. Pellet organik hasil produksi peserta kegiatan dikemas dalam plastik kedap udara dan disimpan dalam tempat yang kering, hingga akhir kegiatan ternyata kondisinya masih baik seperti pada awal penyimpanan, hal ini diduga karena kandungan air pellet $<$ dari $15 \%$ karena proses penjemuran dilakukan selama 3 hari pada kondisi cuaca yang cerah.

Menurut Aslamsyah dan Karim (2013), Cacing tanah (Lumbricus rubellus) memiliki kandungan nutrisi yang dibutuhkan oleh tubuh ikan, sehingga dapat digunakan sebagai pakan. Menurut Fadaee (2012), cacing tanah mengandung protein $65,24 \%$, lemak 11\%, abu 6\% dan nitrogen tanpa ekstrak $19 \%$. Selain mempunyai nilai nutrisi yang baik cacing tanah dapat digunakan sebagai sebagai immunostimulan karena zat aktif yang dimiliki oleh cacing tanah bersifat anti bakteri pathogen (Julendra dan Sofyan, 2007), dapat meningkatkan daya immunitas (Damayanti et al., 2009). Berdasarkan hasil penelitian Aslamsyah dan Karim (2013), bahwa ikan bandeng yang diberi pakan dengan berbagai tingkat substitusi tepung ikan dengan tepung cacing tanah memberikan pengaruh yang sama terhadap konsumsi pakan, efisiensi pakan, retensi protein dan lemak, serta sintasan, komposisi proksimat tubuh, serta kadar glikogen di hati dan otot. Hal tersebut menunjukkan bahwa tepung cacing tanah mampu menggantikan tepung ikan sebagai sumber protein hewani. Selanjutnya menurut Suminto dan Sudaryono (2014), menunjukkan bahwa kombinasi $25 \%$ pakan buatan dan $75 \%$ cacing tanah mampu meningkatkan nilai EPP (Efisisensi Pemanfaatan Pakan) dan SGR (Laju Pertumbuhan Spesifik) dalam budidaya lele dumbo.

\section{KESIMPULAN DAN SARAN}

\section{A. Kesimpulan}

Kegiatan IPTEKS ini dapat disimpulkan sebagai berikut :

1. Terjadi peningkatan pemahaman dan perubahan perilaku petani ikan di Desa Pasir kulon Kecamatan Karang lewas Kabupaten Banyumas dalam melakukan budidaya ikan, khususnya dalam mempersiapkan pakan berupa pakan organik yang bahan bakunya diperoleh di sekitar pemukiman dan tempat budidaya ikan.

2. Petani ikan Desa Pasir Kulon telah mampu memproduksi pakan organik berbahan baku tepung eceng gondok dan cacing tanah yang digunakan untuk penyediaan pakan untuk ikan yang dipelihara dalam skala rumah tangga.

\section{B. Saran}

Untuk meningkatkan kelulushidupan ikan budidaya dan menurunkan biaya pengeluaran karena pakan, dapat dilakukan dengan memproduksi pakan organik berbahan baku tepung eceng gondok dan tepung cacing tanah sebagai pengganti tepung ikan. Selanjutnya untuk meningkatkan nilai cerna dan kandungan nutrisi dalam eceng gondok, dapat dilakukan dengan fermentasi terlebih dahulu. 


\section{UCAPAN TERIMA KASIH}

Terimakasih kepada LPPM (Lembaga Penelitian dan Pengabdian Masyarakat) Unsoed sebagai pemberi dana kegiatan transfer teknologi Pembuatan Pellet Organik Untuk Pakan Ikan Bagi Masyarakat Desa Pasir Kulon, Kecamatan Karanglewas, Kabupaten Banyumas Jawa Tengah. Terimakasih kepada ketua Kelompok pembudidaya ikan Mina Jaya Desa Pasir Kulon Kecamatan Karanglewas, Kabupaten Banyumas, Jawa Tengah.

\section{DAFTAR PUSTAKA}

Afrianto, E., Liviawati, E. 1988. Beberapa Metode Budidaya Ikan. Kanisius, Yogyakarta.

Afrianto, E., Liviawati, E. 2005. Pakan Ikan. Kanisius, Yogyakarta.

Aslamyah, S., Karim M.Y, 2013. Potensi tepung cacing tanah Lumbricus sp. sebagai pengganti tepung ikan dalam pakan terhadap kinerja pertumbuhan, komposisi tubuh, kadar glikogen hati dan otot ikan bandeng Chanos chanos Forsskal. Jurnal Iktiologi Indonesia, 13(1):67-76

Damayanti, E., A. Sofyan, H. Julendra, T. Untari. 2009. Pemanfaatan Tepung Cacing Tanah (Lumbricus rubellus) sebagai Agensia Anti-Pullorum dalam Imbuhan Pakan Ayam Broiler. Jurnal Ilmu Ternak Veteriner 14 (2): 83-89.

Fadee, R. 2012. A Review on Earthworm Esienia fetida and Its Applications. Annals of Biological Research. 3 (5):2500-2506

Iskandar., Elrifadah, 2015. Pertumbuhan Dan Efisiensi Pakan Ikan Nila (Oreochromis niloticus) Yang Diberi Pakan Buatan Berbasis Kiambang (Growth and feed efficiency Tilapia (Oreochromis niloticus) with Salvinia Based Feed. Ziraa'ah, Volume 40 Nomor 1, Pebruari 2015 Halaman 18-24. ISSN ELEKTRONIK 2355-3545

Jangkaru, Z. 1999. Pembesaran Ikan Air Tawar. Penebar Swadaya, Bogor.

Julendra, H., A. Sofyan. 2007. Uji In Vitro Penghambatan Aktivitas Escherichia coli dengan Tepung Cacing Tanah (Lumbricus rubellus). Media Peternakan. Jurnal Ilmu Pengetahuan dan Teknologi Peternakan 30 (1):1-70.

Nugraha, A., Mikdarullah, M. 2016. Teknik Fermentasi Tepung Eceng Gondok Dengan Ragi Tempe Sebagai Alternatif Bahan Baku Pakan Ikan. Buletin Teknik Litkayasa Akuakultur : Volume 13 No 1 (2015).

Ramlan, P., Indrianti, M.A. 2018. Analisa Potensi Eceng Gondok (Eichhornia Crassipes ) Danau Limboto Sebagai Pakan Ternak. Prosiding Seminar Nasional Integrated Farming System, "Pembangunan Pertanian-Peternakan-Perikanan Berkelanjutan Menuju Ketahanan Pangan Nasional” Gorontalo 25-26 November 2018

Taris, M. R., Santoso, L., Harpeni, E. 2018. Pengaruh Subtitusi Tepung Ikan Dengan Tepung Cacing Tanah (Lumbricus Sp.) Terhadap Pertumbuhan Benur Udang Windu (Penaeus monodon). e-Jurnal Rekayasa dan Teknologi Budidaya Perairan Volume VI No 2 Februari 2018 p-ISSN: 2302-3600, e-ISSN: 2597-5315 (C) e-JRTBP Volume 6 No 2 Februari 2018 